\title{
MORPHO-AGRONOMIC AND COOKING QUALITY OF COMMON BEAN (PHASEOLUS VULGARIS L.) GROWN UNDER DIFFERENT NITROGEN SOURCES AND NITROGEN LEVELS
}

\author{
OVACIKLI, E. ${ }^{1}-$ TOLAY, I. ${ }^{2 *}$ \\ ${ }^{I}$ General Directorate of Plant Production Republic of Turkey Ministry of Food Agriculture and \\ Livestock, Eskisehir Road, Ankara, Turkey \\ ${ }^{2}$ Department of Soil Science and Plant Nutrition, Akdeniz University, Faculty of Agriculture, \\ Antalya, Turkey \\ *Corresponding author \\ e-mail: incitolay@akdeniz.edu.tr; phone: +90-242-227-4700; fax: +90-242-227-4564 \\ (Received $19^{\text {th }}$ Jun 2020; accepted $7^{\text {th }}$ Oct 2020)
}

\begin{abstract}
This study aimed to determine the effects of nitrogen $(\mathrm{N})$ doses $\left(0,40,80\right.$ and $\left.120 \mathrm{~kg} \mathrm{~N} \mathrm{ha}^{-1}\right)$ and two different $\mathrm{N}$ fertilizer sources [ammonium nitrate (AN) and calcium ammonium nitrate (CAN)] on yield, yield parameters and quality of common bean (Phaseolus vulgaris L.) grown under the environmental conditions of Central Anatolia, Turkey. Experimental layout was randomized blocks with four replications, and the Önceler-98 bean variety was used as the plant material. The first pod height, number of pods per plant, number of beans per pod, grain yield, 100 grain weight, protein content, wet weight, dry weight, cooking time, water absorption index and swelling capacity of grains were determined. Nitrogen fertilizer sources caused a significant difference $(\mathrm{P}<0.05)$ in 100 grain weight and number of branches per plant. Application of CAN increased the number of branches per plant and AN fertilizer increased the 100 grain weight. The results indicated that the effect of CAN fertilizer is greater compared to AN due to the providing calcium demand of plants grown in soils with low lime content. Higher effect of CAN fertilizer on plant growth can be attributed to the slower solubility of CAN than that of the AN fertilizer. The results concluded that $40 \mathrm{~kg} \mathrm{~N} \mathrm{ha}^{-1}$ may be sufficient to obtain optimum yield, yield parameters and quality of bean, and higher doses of $\mathrm{N}\left(>40 \mathrm{~kg} \mathrm{~N} \mathrm{ha}^{-1}\right)$ applications are not needed.
\end{abstract}

Keywords: bean, yield, yield components, quality, nitrogen, fertilizer source

\section{Introduction}

A large proportion of the protein requirements of people in the world is met by plant sources (Craig, 2009). The highest amount of protein per unit area among the vegetable protein sources is obtained from legumes. Common bean among leguminous crops is rich in vitamins $\mathrm{A}, \mathrm{B}$ and $\mathrm{D}$ and comes to the fore with protein content between 17 and $35 \%$. (Cabrera et al., 2003). Common bean is the most commonly consumed legume and an important nutritional source in the daily diet of more than 300 million people worldwide. The cultivation of common bean is widespread in the temperate regions of the world and $94 \%$ of the production is carried mostly in developing countries of the Asian and South American continents. Application of a fertilizer within the appropriate nutrient/fertilization schedule is of great importance to obtain high yield per unit area in common bean farming.

Plant nutrients are the essential elements for plant growth and each nutrient has specific role in plant growth, thus one element cannot substitute the other. Sepetoglu (1994) reported that harvesting of $180 \mathrm{~kg}$ grain and $160 \mathrm{~kg}$ stem per hectare in bean cultivation removes $165 \mathrm{~kg} \mathrm{ha}^{-1}$ nitrogen $(\mathrm{N}), 70 \mathrm{~kg} \mathrm{ha}^{-1}$ phosphorus $(\mathrm{P}), 137 \mathrm{~kg} \mathrm{ha}^{-1}$ 
potassium (K) and $140 \mathrm{~kg} \mathrm{ha}^{-1}$ calcium (Ca) from soil. Nitrogen is one of the most important inputs in plant production. Despite the $\mathrm{N}$ fixing ability of legumes, $\mathrm{N}$ fertilizers are needed in sowing. The bean plant can meet most of the $\mathrm{N}$ needed by fixing the free $\mathrm{N}$ in atmosphere through the rhizobium bacteria, which have a symbiosis with bean plants in soil. The amount of $\mathrm{N}$ fixed through the symbiosis between rhizobium and edible legume varies depending on the crop type and environmental conditions and was reported ranging from 5 to $20 \mathrm{~kg}$ per year (Sehirali, 1988). Total amount of $\mathrm{N}$, which is biologically bound on legumes in 0.3 million ha lands in Nepal, was estimated as $30 \times 103$ tons per year (Maskey et al., 2001), and approximately 50\% of $\mathrm{N}$ is provided by the symbiosis between legume and rhizobium (Smil, 2002). However, nitrogen, which is needed until growing sufficient number of rhizobium bacteria in soil and establishing a symbiosis with the bean plants, should be applied to soil as the starting fertilizer. An optimum $\mathrm{N}$ nutrition by natural mineral $\mathrm{N}$ content of soils cannot be expected under insufficient $\mathrm{N}$ fertilization and without bacterial inoculation to the bean plants (Zahran, 1999). The $\mathrm{N}$ content of soils depends on many factors such as parent material of soils, soil organic matter content, microbiological condition and climate. Therefore, plant available $\mathrm{N}$ forms in agricultural soils are rapidly lost depending on environmental conditions.

The optimum/balanced nutrition of plants is an extremely important factor on quality as well as yield. Soil fertility management beside yield may also affect the nutritional and so cooking quality of seeds (Alamu et al., 2019) For example, the weight of chickpea grains increases by 54 to $133 \%$ after swelling in water for 18 to $24 \mathrm{~h}$, and cooking and swelling for 45 to $90 \mathrm{~min}$, sometimes $2 \mathrm{~h}$. Calcium concentration of shells was reported effective on the cooking quality of grains. Therefore, quality of grains produced in soils with low lime content was reported poor (Sehirali, 1988). Calcium ammonium nitrate is one of the most commonly used $\mathrm{N}$ fertilizers in plant production in Turkey as well as in the world. However, the CAN fertilizer may have even more adverse effect locally on these values in soils with high $\mathrm{pH}$ value and lime content. Cultivation of the beans under such conditions and/or continuous application of CAN fertilizer, which contains Ca will negatively affect the cooking quality.

The aim of this study was to reveal the effects of two different $\mathrm{N}$ fertilizer sources (ammonium nitrate; AN and calcium ammonium nitrate; $\mathrm{CAN}$ ) and increasing doses of $\mathrm{N}\left(0,40,80\right.$ and $\left.120 \mathrm{~kg} \mathrm{ha}^{-1}\right)$ on yield, yield parameters and cooking quality of Önceler98 bean variety.

\section{Material and methods}

\section{Soil and climatic characteristics of the experimental field}

The field experiment was conducted under ecological conditions of Eskisehir province, Turkey in 2007. Experimental field was located in the research farm of Agricultural Faculty in Eskisehir Osmangazi University $\left(39^{\circ} 48^{\prime} \mathrm{N} ; 30^{\circ} 31^{\prime} \mathrm{E}, 798 \mathrm{~m}\right.$ above sea level). Surface soils $(0-30 \mathrm{~cm})$ of the experimental field were low in organic matter content, moderate in lime content, non-saline, loamy textured and slightly alkaline (Table 1). The winters in the study area are usually cold and rainy and the summers are hot and dry. Long term (1928-2019) average annual total precipitation is $374.2 \mathrm{~mm}$ and average precipitation is $11.2{ }^{\circ} \mathrm{C}$. The coldest month is January with an average temperature of $0{ }^{\circ} \mathrm{C}$, while the highest average temperature $\left(21.8^{\circ} \mathrm{C}\right)$ was recorded in July and August (Anonymous, 2020). Total precipitation from seed sowing 
to harvest (between April and November), was $262 \mathrm{~mm}$, average monthly temperature was $16^{\circ} \mathrm{C}$ and relative humidity was $51.4 \%$.

Particle size distribution of soil samples were determined according to hydrometer method (Bouyoucos, 1951) Soil $\mathrm{pH}$ and electrical conductivity were measured in 1:2.5 (soil:water) mixture using a $\mathrm{pH}$-EC meter (Jackson, 1958), and calcium carbonate content (\%) was determined using a Scheibler calcimeter (Allison and Moodie, 1965). Organic matter content (\%) of soil samples were analyzed by using the modified Walkley-Black method (Nelson and Sommers, 1982). Plant available phosphorus was analyzed by the method of Olsen (1954) using Termo-aquamete UV spectrophotometer and extractable potassium was determined according to Thomas (1982) using the BWB/XP2011 model flame photometer.

Table 1. Some physical and chemical properties of experimental field

\begin{tabular}{c|c|c|c|c|c|c}
\hline \multirow{2}{*}{ Soil texture } & \multirow{2}{*}{$\mathbf{p H}$} & \multirow{2}{*}{ Total salt (\%) } & \multirow{2}{*}{ Organic matter (\%) } & \multirow{2}{*}{$\mathrm{CaCO}_{3}(\%)$} & \multicolumn{2}{|c}{ Available (mg kg-1) } \\
\cline { 5 - 7 } & & & & $\mathbf{P}$ & $\mathbf{K}$ \\
\hline Loam & 8.10 & 0.05 & 1.70 & 4.36 & 6.73 & 721.3 \\
\hline
\end{tabular}

\section{Establishment of the experiment}

Local dwarf Önceler-98 bean variety (Phaseolus vulgaris L.) was used as a plant material of the experiment. Four different $\mathrm{N}$ doses $\left(0,40,80\right.$ and $\left.120 \mathrm{~kg} \mathrm{ha}^{-1}\right)$ and two different $\mathrm{N}$ sources (fertilizers) [ammonium nitrate (AN) $33 \% \mathrm{~N},\left(\mathrm{NH}_{4} \mathrm{NO}_{3}\right)$ and calcium ammonium nitrate $\left.(\mathrm{CAN}) 26 \% \mathrm{~N},\left(5 \mathrm{Ca}\left(\mathrm{NO}_{3}\right) 2 \mathrm{NH}_{4} \mathrm{NO}_{3} \cdot 10 \mathrm{H}_{2} \mathrm{O}\right)\right]$ were applied during seed sowing. Triple superphosphate $\left(80 \mathrm{~kg} \mathrm{P}_{2} \mathrm{O}_{5} \mathrm{ha}^{-1}\right)$ was applied during tillage before planting (Sehirali, 1988). The experimental layout was a split-plots in a randomized complete block design with three replications. The $\mathrm{N}$ fertilizers were placed in the main plots and $\mathrm{N}$ doses were in the subplots.

Seeds were manually sown on April 28, 2007 at an inter row spacing of $60 \mathrm{~cm}$ and an intra row spacing of $20 \mathrm{~cm}$ in four rows. The length of individual plots was $5 \mathrm{~m}$ and total area of each plot was $12 \mathrm{~m}^{2}$. Weed control in the experiment was carried out manually using a hoe. The water requirement of plants, especially during the flowering $(77 \mathrm{~mm})$ and pod formation $(100 \mathrm{~mm})$ periods, was met by drip irrigation. The amount of irrigation water was calculated aiming to complete the water added to soil including the total rainfall in vegetation period to $439 \mathrm{~mm}$ which is considered the requirement of the bean plants (Silim and Saxena, 1993).

\section{Yield and agronomic characteristics of common bean}

All plants were harvested on September 2 following the ripening and drying, and the grain yield $\left(\mathrm{kg} \mathrm{ha}^{-1}\right)$ was calculated after separating and weighing the grains. Above ground parts of 10 bean plants were cut in each plot to determine the effects of $\mathrm{N}$ doses and fertilizer sources. The first pod height $(\mathrm{cm})$ per plant, number of pods per plant, number of main branches per plant and the number of beans per pod were determined in 10 bean plants. One hundred dry beans were weighed to determine the dry weight of grains.

For wet weight of bean grains, dry weights of 100 bean seeds were recorded, then dry seeds were soaked for $16 \mathrm{~h}$, and extra water was poured, the seeds were dried and weighed. Water absorption capacity of beans were calculated as follows (Eq. 1): 
In the equation: IW is the sample initial weight (g/grain); DW is the sample final dry weight.

Water absorption index was calculated as follows (Eq. 2):

$$
\text { Water absorption index }=(\mathrm{IW}) / \mathrm{DW}) / 100)
$$

Swelling capacity (SC) was determined as follows (Eq. 3):

$$
\mathrm{SC}=[(\mathrm{WV}-100)-(\mathrm{DV}-50)]-[\mathrm{DV}-50 / 100) \times \mathrm{NNSG} / 100 \mathrm{NNSG}]
$$

In the equation: WV is the wet volume; DV is the dry volume; NNSG is the number of non-swollen grains $\left(\mathrm{ml}\right.$ grain $\left.^{-1}\right)$.

Swelling index (\%), cooking time (minutes) and protein content (using Kjeldahl Method by Bremner, 1965) using by Gerhardt Kjeldahl distillation system (Vapodest ${ }^{\circledR}$ $200-450$ ) of common bean grains were also determined as quality parameters.

The treatment effects on yield, yield components and quality of common bean were assessed by analysis of variance (ANOVA) using SPSS 20.0 software. The mean values were compared by Turkey's test at $5 \%$ probability level when significant $F$ values $(\mathrm{P}<0.05)$ were obtained in the ANOVA test.

\section{Results and discussion}

\section{Morphological characteristics of plants}

The first pod height of bean plants, the number of pods per plant, the number of branches per plant and the number of seeds per pod were given in Table 2. The $\mathrm{N}$ resources had a significant effect $(\mathrm{P}<0.05)$ only on the first pod height of the plants. The mean first pod height of plant was $17.47 \mathrm{~cm}$ in control treatment, and the highest pod height $(19.11 \mathrm{~cm})$ was recorded in $40 \mathrm{~kg} \mathrm{ha}^{-1}$ doses of CAN fertilizer treatment. The first pod height increase in CAN $(18.11 \mathrm{~cm})$ application was higher compared to the AN $(17.89 \mathrm{~cm})$ fertilizer application. The most effective $\mathrm{N}$ dose for the first pod height increase in both fertilizers was obtained with $40 \mathrm{~kg} \mathrm{~N} \mathrm{ha}^{-1}$.

The first pod height, which is an important characteristic to facilitate machine harvest and reduce harvest losses (Cober et al., 2000), was increased compared to control with the $\mathrm{N}$ applications. Similar to the findings obtained in common bean, Oz (2008) reported the first pod height increase in soybean with the $\mathrm{N}$ application. The first pod heights of bean varieties were reported ranging between 13.3 and $18.1 \mathrm{~cm}$ (Anlarsal et al., 2000). Onder et al. (2013) reported that cultivation techniques (sowing density, fertilization, etc.) and different environmental conditions significantly affect the first pod height (Onder et al., 2013). Therefore, the first pod height should not be very low to reduce losses in the machine harvest of beans (Gunes, 2006).

The effects of $\mathrm{N}$ sources on the number of pods per plant was not significant while $\mathrm{N}$ doses and $\mathrm{N}$ source $\times \mathrm{N}$ dose interaction had a significant effect $(\mathrm{P}<0.05)($ Table 2). The highest number of pods per plant was obtained in $40 \mathrm{~kg} \mathrm{~N}^{-1}$ dose (24.36 pods) and CAN fertilizer (23.32 pods) treatments. Application of CAN fertilizer at $40 \mathrm{~kg} \mathrm{~N} \mathrm{ha}^{-1}$ dose had a significant effect on the number of pods per plant (25.39 pods). The highest application dose $\left(40 \mathrm{~kg} \mathrm{~N} \mathrm{ha}^{-1}\right)$ of the CAN fertilizer had a more pronounced effect on the 
number of pods compared to other doses, however, all doses of the AN fertilizer had an effect on increasing the number of pods per plant. Nitrogen is an important nutrient in plant nutrition that affects cell division and elongation and plays a role in pod formation (Abo-Sedera et al., 2016). Several reports published stated that the number of pods per bean plant ranges between 4 and 14 pods, and $\mathrm{N}$ applications has a direct impact on grain yield (Peksen, 2005; Fageria et al., 2011; Fernández-Luqueño et al., 2010).

The source of $\mathrm{N}$ fertilizer had a significant effect $(\mathrm{P}<0.05)$ on the increase in number main branches per plant, and higher number of branches per plant (2.17 branches) were obtained with CAN fertilizer application. Branching is closely related to the sowing density and branching is decreased in the close inter row spacing between bean plants, while branching is increased at wide sowing distances. Branching in bean is a desired characteristic, and the increase in the number of branches increases the number of leaves per plant. The increase in plant growth increases the number of pods per plant, thus resulting in high yields (Karasu and Oz, 2010; Abo-Sedera et al., 2016). The number of branches per bean plant has been reported between 2.2 and 3.7 branch plant $^{-1}$ (Dumlu, 2009). The increase or decrease in the number of branches per bean plant has been attributed to the differences in soil characteristics and climate of the study area, and genetic materials and fertilizer sources used in the experiment (Abo El-Yazied et al., 2012).

The $\mathrm{N}$ sources and doses did not have a significant effect on the number of grain per pod (Table 2). However, $\mathrm{N}$ doses increased the number of grains per pod compared to the plants in control treatment. Oz (2002) and Kacar et al. (2004) reported that the N doses increased the number of grains per pod. In contrast, Franco et al. (2008) determined that $\mathrm{N}$ dose did not cause a significant difference in the number of grains per pod. The number of grains per pod was reported ranging between 3.24 and 6.06 grains and this number varies depending on the characteristics of a genotype (Anlarsal et al., 2000; Peksen, 2005).

Table 2. Effects of $N$ sources and $N$ doses on some of quality parameters of common bean

\begin{tabular}{|c|c|c|c|c|c|c|c|c|}
\hline \multirow[b]{2}{*}{ Rates } & \multicolumn{2}{|c|}{ First pod height } & \multicolumn{2}{|c|}{$\begin{array}{l}\text { The number } \\
\text { of pods } \\
\text { per plant } \\
\left(\text { pod plant }^{-1}\right)\end{array}$} & \multicolumn{2}{|c|}{$\begin{array}{c}\text { The number of } \\
\text { main branches per } \\
\text { plant } \\
\text { (branch plant }^{-1} \text { ) }\end{array}$} & \multicolumn{2}{|c|}{$\begin{array}{l}\text { The number } \\
\text { of grains } \\
\text { per pod } \\
\left(\text { grain pod }^{-1}\right)\end{array}$} \\
\hline & AN & CAN & AN & CAN & AN & CAN & AN & CAN \\
\hline N0 & 17.47 & 17.83 & $14.47 \mathrm{c}$ & $23.32 \mathrm{ab}$ & 1.51 & 2.31 & 3.54 & 3.63 \\
\hline N40 & 18.19 & 19.11 & $23.31 \mathrm{ab}$ & $25.39 \mathrm{a}$ & 2.01 & 2.18 & 3.76 & 3.84 \\
\hline N80 & 17.74 & 17.71 & $22.15 \mathrm{ab}$ & $21.04 \mathrm{ab}$ & 1.98 & 2.03 & 3.78 & 3.55 \\
\hline N120 & 18.19 & 17.75 & $19.00 \mathrm{bc}$ & $23.52 \mathrm{ab}$ & 1.61 & 2.15 & 3.84 & 3.85 \\
\hline Mean & 17.89 & 18.11 & 19.74 & 23.32 & $1.78 b$ & $2.17 a$ & 3.73 & 3.72 \\
\hline N0 & \multicolumn{2}{|c|}{$17.65 \mathrm{~b}$} & \multicolumn{2}{|c|}{18.9} & \multicolumn{2}{|c|}{1.91} & \multicolumn{2}{|c|}{3.59} \\
\hline N40 & \multicolumn{2}{|c|}{$18.65 \mathrm{a}$} & \multicolumn{2}{|c|}{24.36} & \multicolumn{2}{|c|}{2.11} & \multicolumn{2}{|c|}{3.81} \\
\hline N80 & \multicolumn{2}{|c|}{$17.73 \mathrm{~b}$} & \multicolumn{2}{|c|}{21.6} & \multicolumn{2}{|c|}{2.01} & \multicolumn{2}{|c|}{3.67} \\
\hline N120 & \multicolumn{2}{|c|}{$17.97 \mathrm{ab}$} & \multicolumn{2}{|c|}{21.27} & \multicolumn{2}{|c|}{1.89} & \multicolumn{2}{|c|}{3.85} \\
\hline \multicolumn{9}{|l|}{ F test } \\
\hline Source $(\mathrm{S})$ & \multicolumn{2}{|c|}{ ns } & \multicolumn{2}{|c|}{ ns } & \multicolumn{2}{|c|}{ * } & \multicolumn{2}{|c|}{ ns } \\
\hline Rate (R) & \multicolumn{2}{|c|}{ * } & \multirow{2}{*}{\multicolumn{2}{|c|}{ * }} & \multicolumn{2}{|c|}{$\mathrm{ns}$} & \multicolumn{2}{|c|}{$\mathrm{ns}$} \\
\hline $\mathrm{S} \times \mathrm{R}$ & \multicolumn{2}{|c|}{ ns } & & & \multicolumn{2}{|c|}{ ns } & \multicolumn{2}{|c|}{ ns } \\
\hline
\end{tabular}

${ }^{*} \mathrm{P}<0.05$; ns: not significant 
The effects of $\mathrm{N}$ source and $\mathrm{N}$ doses had no significant impact on bean grain yield, while $\mathrm{N}$ source $\times \mathrm{N}$ dose interaction significantly $(\mathrm{P}<0.01)$ affected the grain yield (Table 3). Average grain yield varied between 1876.1 and $2089.6 \mathrm{~kg} \mathrm{ha}^{-1}$ and the highest grain yield $\left(2160.3 \mathrm{~kg} \mathrm{ha}^{-1}\right)$ was obtained from $40 \mathrm{~kg} \mathrm{~N} \mathrm{ha}^{-1}$ dose. The highest grain yield (2230.9 $\mathrm{kg} \mathrm{ha}^{-1}$ ), in terms of $\mathrm{N}$ source was recorded in $40 \mathrm{~kg} \mathrm{~N}^{-1}$ dose of CAN fertilizer application. The reports on the optimum $\mathrm{N}$ dose needed to obtain the highest grain yield are not consistent. Silva (2020) obtained the highest grain yield in common bean with the application of $100 \mathrm{~kg} \mathrm{~N} \mathrm{ha}^{-1}$ nitrogen. In other studies, Valerio et al. (2003) stated that $80 \mathrm{~kg} \mathrm{ha}^{-1}$ yields the highest grain yield, Kacar et al. (2004) stated as $90 \mathrm{~kg} \mathrm{ha}^{-1}$ and Kaneko et al. (2010) stated as $180 \mathrm{~kg} \mathrm{ha}^{-1} \mathrm{~N}$. In this study, the highest number of pods per plant was determined at $40 \mathrm{~kg} \mathrm{ha}^{-1}$ dose of CAN fertilizer. Similarly, others stated that the grain yield is affected by the number of pods per plant (Soratto et al., 2017; Carvalho et al., 2018; Chekanai et al., 2018).

Fertilizer sources had a significant effect on 100 hundred grain weight of bean ( $\mathrm{P}<0.05)$, while the effect of $\mathrm{N}$ doses on 100 grain yield was not significant. The mean 100 grain weight (42.44 g) obtained in AN application was higher than that (41.35 g) of the CAN application (Table 3). Some studies reported an increase also in 100 grain weight with the $\mathrm{N}$ applications (Oz, 2008; Nascente et al., 2017). Fageria et al. (2014) indicated that the increased doses of $\mathrm{N}$ increased the 100-grain weight of different bean varieties, which responded differently to the interactions of $\mathrm{N} \times$ genotype.

Table 3. Effects of $N$ sources and $N$ doses on grain yield, hundred grain weight and grain protein content of common soybean

\begin{tabular}{|c|c|c|c|c|c|c|}
\hline \multirow[b]{2}{*}{ Rates } & \multicolumn{2}{|c|}{$\begin{array}{l}\text { Grain yield } \\
\left(\mathrm{kg} \mathrm{ha}^{-1}\right)\end{array}$} & \multicolumn{2}{|c|}{$\begin{array}{l}\text { Hundred grain weight } \\
\text { (g) }\end{array}$} & \multicolumn{2}{|c|}{$\begin{array}{c}\text { Grain protein content } \\
(\%)\end{array}$} \\
\hline & AN & CAN & AN & CAN & $\mathrm{AN}$ & CAN \\
\hline No & $1876.1 \mathrm{~cd}$ & $1857.4 \mathrm{~d}$ & 42.25 & 41.62 & 25.27 & 25.69 \\
\hline N40 & $2089.6 \mathrm{ab}$ & $2230.9 \mathrm{a}$ & 42.33 & 41.59 & 24.07 & 26.6 \\
\hline N80 & $1995.6 \mathrm{bd}$ & $2017.6 \mathrm{bc}$ & 41.84 & 40.93 & 23.71 & 24.35 \\
\hline N120 & $2034.3 \mathrm{~b}$ & $1995.1 \mathrm{bd}$ & 43.36 & 41.27 & 25.98 & 24.43 \\
\hline Mean & 1998.9 & 2025.2 & $42.44 a$ & $41.35 b$ & 24.76 & 25.27 \\
\hline No & \multicolumn{2}{|c|}{1866.8} & \multicolumn{2}{|c|}{41.94} & \multicolumn{2}{|c|}{25.49} \\
\hline N40 & \multicolumn{2}{|c|}{2160.3} & \multicolumn{2}{|c|}{41.96} & \multicolumn{2}{|c|}{25.34} \\
\hline N80 & \multicolumn{2}{|c|}{2006.6} & \multicolumn{2}{|c|}{41.39} & \multicolumn{2}{|c|}{24.04} \\
\hline N120 & \multicolumn{2}{|c|}{2014.7} & \multicolumn{2}{|c|}{42.32} & \multicolumn{2}{|c|}{25.22} \\
\hline \multicolumn{7}{|l|}{$F$ test } \\
\hline Source $(S)$ & \multicolumn{2}{|c|}{ ns } & \multicolumn{2}{|c|}{$*$} & \multicolumn{2}{|c|}{ ns } \\
\hline Rate (R) & \multicolumn{2}{|c|}{ ns } & \multicolumn{2}{|c|}{$\mathrm{ns}$} & \multicolumn{2}{|c|}{ ns } \\
\hline $\mathrm{S} \times \mathrm{R}$ & \multicolumn{2}{|c|}{$* *$} & \multicolumn{2}{|c|}{ ns } & \multicolumn{2}{|c|}{$\mathrm{ns}$} \\
\hline
\end{tabular}

${ }^{*} p<0.05 ; * *<0.01$; ns: not significant, $\mathrm{AN}$ : ammonium nitrate, CAN: calcium ammonium nitrate

\section{Quality parameters of common bean}

Nitrogen sources and doses did not have a significant effect on the protein content of bean grains (Table 3). The CAN fertilizer caused a higher increase in protein content compared to AN fertilizer, and the highest grain protein content $(26.60 \%)$ was obtained by $40 \mathrm{~kg} \mathrm{~N} \mathrm{ha}^{-1}$ dose of CAN fertilizer treatment. Beans are very important nutrient 
sources in human nutrition in terms of protein, vitamins, minerals and fiber sources (Kutos et al., 2003). Application of organic nutrient-containing fertilizers together with mineral fertilizers reported increasing the protein content of legumes (Jagannath et al., 2002; Hegazi et al., 2011). The researchers reported that protein content varies depending on fertilization, irrigation, climate and soil characteristics (Kose et al., 2019; Gulmezoglu and Kayan, 2011). The protein content of bean grains has been reported varying between 20.11 and 28.62\% (Kahraman and Onder, 2013; Chavez-Mendoza et al., 2010).

Different $\mathrm{N}$ sources and doses did not have a significant effect on the cooking time of bean grains $(\mathrm{p}>0.05)$. The cooking time of bean grains ranged from 23 to $25.50 \mathrm{~min}$ (Fig. 1). The cooking time obtained in the AN fertilizer application was longer than the beans obtained in CAN fertilizer application. Longer cooking time of bean grain has been attributed to the hard shell that does not allow the grain to be soaked sufficiently or to absorb water (Saha et al., 2009). Similar to the results obtained in this study, Kigel (1999) reported that cooking the bean grains is a problem. Akdag (1996) found that the cooking time of leguminous grains are affected by the growing conditions, thickness and chemical composition of the grain shell as well as the genetic characteristics. The factors such as early harvest, cultivation in soils with high $\mathrm{Ca}$ and $\mathrm{Mg}$ concentrations and storage under improper conditions (higher than $13-14 \%$ humidity and $100{ }^{\circ} \mathrm{C}$ storage temperature levels) negatively affect the cooking quality of edible legumes. Some studies reported that the cooking time of bean grains varies between 23 and 47 min (Shimelis and Rakshit, 2005; Perina et al., 2014). Cooking of edible legume grains is defined as gelatinization of starch, as well as softening of the grain and becoming easily chewable in the mouth. The definition of cooking implies that the grain shell of a bean is affected by hot water permeability, chemical composition of the cell wall, inherited hardness of cotyledon and physical properties of the grain (Carvalho et al., 2017). In addition, factors such as grain shell composition, environmental conditions, storage conditions and chemical composition also have an effect on cooking time (Shimelis and Rakshit, 2005).

The effects of fertilizer type, $\mathrm{N}$ application dose and their interactions on water absorption capacity were not statistically significant. The water absorption capacity of bean grains in this study was between 0.378 and $0.430 \mathrm{~g}_{\text {grain }}{ }^{-1}$. The highest water absorption capacity of bean grains was recorded in CAN fertilizer application and the water absorption capacity of grains decreased with the $\mathrm{N}$ application ratios (Fig. 1). The water absorption capacity of bean grains was reported ranging between 0.146 and $0.809 \mathrm{~g} \mathrm{grain}^{-1}$ by Ozbekmez (2015) while between 0.168 and $0.487 \mathrm{~g}_{\text {grain }}{ }^{-1}$ by Cengiz (2007). The water absorption capacity varies depending on the composition of grains, the cell wall structure and the condition of cells in the grains. Therefore, a strong positive relationship has been reported between grain mass and water absorption capacity (Kaur and Sing, 2006).

Water absorption index ranged from $0.88-1.03 \%$, and the highest water absorption index in the grain was obtained in CAN application. However, the effects of $\mathrm{N}$ sources and doses on water absorption index were not statistically significant. The water absorption index values of the bean grains obtained in this study were compatible with the findings of Cengiz (2007) (0.963-1.157\%) and Ozbekmez (2015) (0.323-1.780\%).

Average swelling capacity $\left(\mathrm{ml} \mathrm{grain}^{-1}\right)$ varied between 0.37 and $0.49 \mathrm{ml} \mathrm{grain}^{-1}$ depending on $\mathrm{N}$ sources and doses. The grain swelling capacity was higher under AN application compared to that of CAN application and the swelling capacity of bean grains decreased with the $\mathrm{N}$ doses. The results obtained are similar to the findings of Cengiz (2007) (0.125-0.420 ml grain $\left.{ }^{-1}\right)$ and Ozbekmez (2015) (0.104-0.574 ml grain $\left.{ }^{-1}\right)$. 


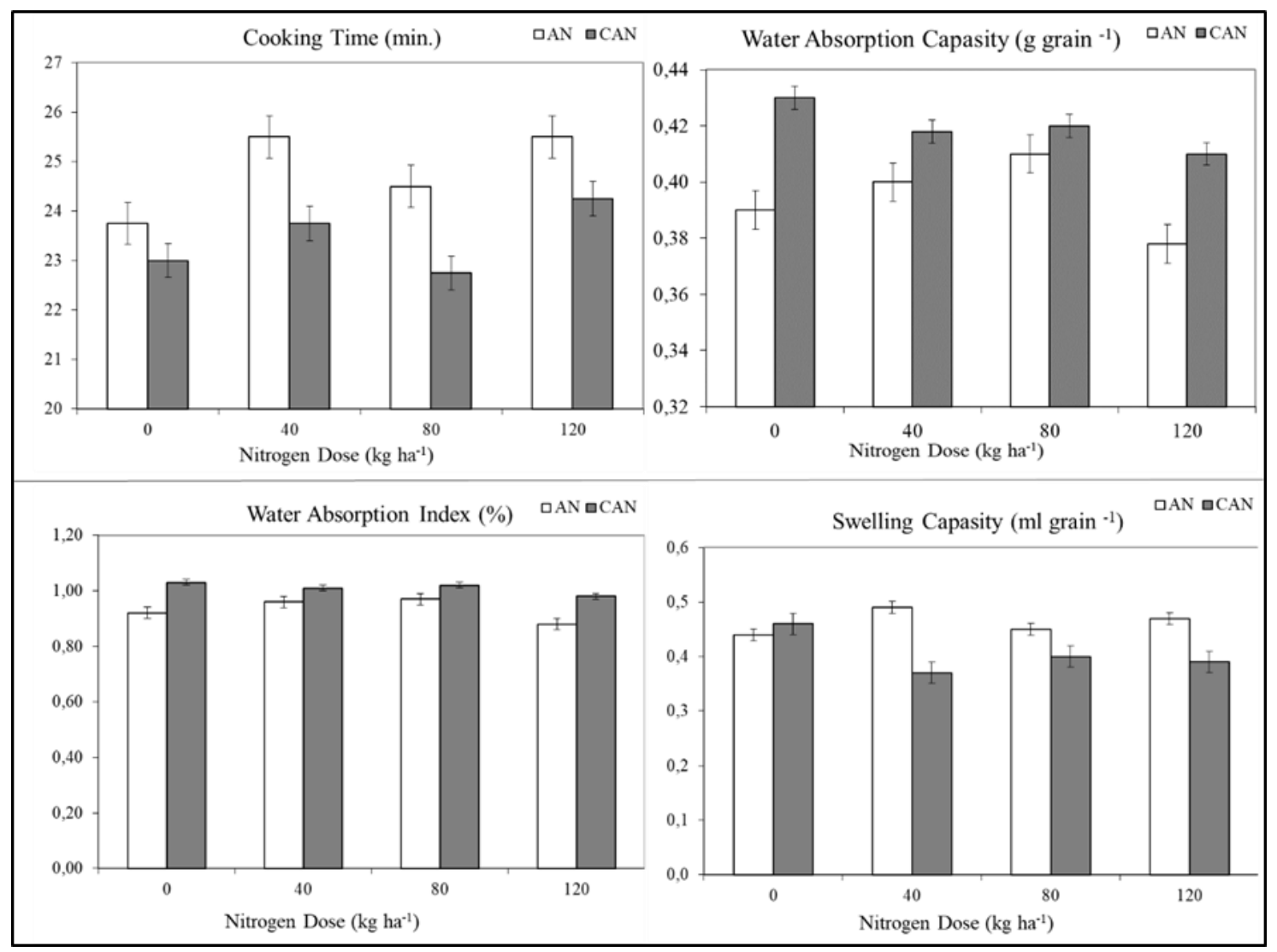

Figure 1. Effects of $N$ doses on cooking time, water absorption capacity, water absorption index and swelling capacity of bean grains

\section{Conclusions}

The results revealed that application of CAN fertilizers in alkaline soils during bean production does not have a negative impact on the bean growth by the increasing soil $\mathrm{pH}$, and on the bean grain quality due to the addition of $\mathrm{Ca}$. The application of AN fertilizer had a significant effect $(\mathrm{P}<0.05)$ only on 100-grain weight, while CAN fertilizer caused a statistically significant $(\mathrm{P}<0.05)$ increase in the number of pods per plant, which is the most important grain yield parameter of the beans. In addition, although not statistically significant, the effects of CAN fertilizer on all yield components were more positive than that of the AN fertilizer. This positive effect may be related to the rapid dissolution of the AN relative to the CAN fertilizer and subsequent $\mathrm{N}$ losses in AN applied fields. The results obtained in this study also indicated that $40 \mathrm{~kg} \mathrm{~N} \mathrm{ha}^{-1}$ application dose may be sufficient to obtain desired yield components and quality of the beans. Therefore, higher $\mathrm{N}$ doses than the plant requirements can cause environmental pollution as well as economic losses. The results indicated that application of $40 \mathrm{~kg} \mathrm{~N} \mathrm{ha}^{-1} \mathrm{CAN}$ fertilizer at the beginning until the bean plant can establish a symbiotic life with the natural rhizobium of the soil does not cause a decrease in grain yield. Application of CAN fertilizer even had a more positive effect than AN, however CAN fertilizer could have a slightly negative effect on cooking time of bean grains. This study should be repeated using different bean varieties, locations, $\mathrm{N}$ sources and in varied climatic conditions. 


\section{REFERENCES}

[1] Abou El-Yazied, A., El-Gizawy, A. M., Ragab, M. I., Hamed, E. S. (2012): Effect of seaweed extract and compost treatments on growth, yield and quality of snap beans. Journal of American Science 8(6): 1-20.

[2] Abo-Sedera, F. A., Shams, A. S., Mohamed, M. H. M., Hamoda, A. H. M. (2016): Effect of organic fertilizer and foliar spray with some safety compounds on growth and productivity of snap bean. - Annals of Agricultural Science Moshtohor 54(1): 105-118.

[3] Akdag, C., Tayyar, I. (1996): A study on determining the most suitable sowing density for common beans in Tokat ecological conditions. - Turkish Journal of Agriculture and Forestry 20: 199-205 (in Turkish with English abstract).

[4] Alamu, E. O., Gondwe, T., Akinwale, G., Suzuki, K., Chisong, C., Chigeza, G. and Busie, M. D. (2019): Impact of soil fertility management practices on the nutritional quality of soybean (Glycine max (1.) Merr.) varieties grown in Eastern Zambia. - Cogent Food and Agriculture, London 5(1): 671117.

[5] Allison, L. E., Moodie, C. D. (1965): Carbonate. - In: Page, A. L. et al. (eds.) Methods of Soil Analysis. Part 2 Chemical and Microbiological Properties. ASA, Madison, WI, pp. 1379-1396.

[6] Anlarsal, A. E., Yucel, C., Ozveren, D. (2000): Determination of seed yield and yield components in some bean (Phasalis vulgaris L.) cultivars and correlations between these characters under the Cukurova conditions. - Turkish Journal of Agriculture and Forestry $-24,19-29$.

[7] Anonymous (2020): Ministry of Agriculture and Forestry, General Directorate of Meteorology. $\quad-\quad$ https://www.mgm.gov.tr/veridegerlendirme/il-ve-ilceleristatistik.aspx?m=ESKISEHIR. Accessed on August 14, 2020.

[8] Bremner, J. M. (1965): Organic Forms of Nitrogen. - In: Page, A. L. et al. (eds.) Methods of Soil Analysis. Part 2 Chemical and Microbiological Properties. ASA, Madison, WI, pp. 1238-1255.

[9] Bouyoucos, G. J. (1951): A recalibration of the hydrometer method for making mechanical analysis of soils 1. - Agronomy Journal 43(9): 434-438.

[10] Cabrera, C., Loris, F., Gimenez, R., Olalla, M., Lopez, M. C. (2003): Mineral contenting legumes and nuts: Contribution to the Spanish dietary intake. - Science of the Total Environment 308: 1-14.

[11] Carvalho, B. L., Ramalho, M. A. P., Júnior, V., Cunha, I., Abreu, Â. D. F. B. (2017): New strategy for evaluating grain cooking quality of progenies in dry bean breeding programs. - Crop Breeding and Applied Biotechnology 17(2): 115-123.

[12] Carvalho, M. D., Nascente, A. S., Ferreira, G. B., Mutadiua, C. A., Denardin, J. E. (2018): Phosphorus and potassium fertilization increase common bean grain yield in Mozambique. - Revista Brasileira de Engenharia Agrícola e Ambiental 22(5): 308-314.

[13] Cengiz, B. (2007): Quality characteristics of some common bean varieties grown in Sakarya and Eskişehir locations. - Master Thesis, Namık Kemal University, Institute of Science, Tekirdag, Turkey (in Turkish with English abstract).

[14] Chávez-Mendoza, C., Hernández-Figueroa, K., Sánchez, E. (2019): Antioxidant capacity and phytonutrient content in the seed coat and cotyledon of common beans (Phaseolis vulgaris L.) from various regions in Mexico. - Antioxidants 8(1): 5.

[15] Cober, E. R., Madill, J., Voldeng, H. D. (2000): Early tall determinate soybean genotype E1E1e3e3e4e4dt1dt1 sets high bottom pods. - Canadian Journal of Plant Science 80(3): 527-531.

[16] Craig, W. J. (2009): Health effects of vegan diets. - American Journal of Clinical Nutrition 89(5): 1627-1633.

[17] Dumlu, B. (2009): Phenological and morphological characterization of 23 bean (Phaseolus vulgaris L.) genotypes collected from North Eastern Anatolia Region. - 
Master Thesis, Atatürk University Institute of Science Field Crops Department, Erzurum (in Turkish with English abstract).

[18] Fageria, N. K., Melo, L. C., Ferreira, E. P. B., Oliveira, J. P., Knupp, A. M. (2014): Dry matter, grain yield, and yield components of dry bean as influenced by nitrogen fertilization and rhizobia. - Communications in Soil Science and Plant Analysis 45(1): 111-125.

[19] Fernández-Luqueño, F., Reyes-Varela, V., Martínez-Suárez, C., Salomón-Hernández, G., Yáñez-Meneses, J., Ceballos-Ramírez, J. M., Dendooven, L. (2010): Effect of different nitrogen sources on plant characteristics and yield of common bean (Phaseolus vulgaris L.). - Bioresource Technology 101(1): 396-403.

[20] Franco, E., Andrade, C. A. A. B., Scapim, C. A., Freitas, P. S. L. (2008): Response of the common bean to nitrogen application at sowing and topdressing in non-tillage systems. Acta Scientiarum: Agronomy 30(3): 427-434.

[21] Gulmezoglu, N., Kayan, N. (2011): Common matter and nitrogen accumulation during vegetative and grain filling of lentil (Lens culinaris Medic.) as affected by nitrogen rate. Notulae Botanicae Horti Agrobotanici Cluj-Napoca 39(2): 196-202.

[22] Gunes, A. (2006): The Effect of Different Nitrogen Doses and Application Times on Yield and Yield Components of Second Crop Soybean (Glycine Max L. Merrill) Agriculture. - Master Thesis, Harran University, Graduate School of Science (in Turkish with English abstract).

[23] Hegazi, A. Z., Mostafa, S. S., Ahmed, H. M. (2010): Influence of different cyanobacterial application methods on growth and seed production of common bean under various levels of mineral nitrogen fertilization. - Nature and Science 8(11): 183-194.

[24] Jackson, M. L. (1958): Soil Chemical Analysis. - Prentice Hall Inc., Englewood Cliffs, NJ.

[25] Jagannath, S. B. A., Dengi, U., Sedamakar, E. (2002): Algalization studies on chickpea (Cicer arietinum L). - Biotechnology of Microbes and Sustainable Utilization 3:145-150.

[26] Kacar, O., Cakmak, F., Coplu, N., Azkan, N. (2004): The effect of bacterial inoculation and different nitrogen doses on yield and yield components of some common bean varieties (Phaseolus vulgaris L.) under Bursa conditions. - Journal of Uludag University, Faculty of Agriculture 18(1): 207-218 (in Turkish with English abstract).

[27] Kahraman, A., Onder, M. (2013): Correlations between seed color and nutritional composition of common bean. - Ratarstvo i povrtarstvo 50(2): 8-13.

[28] Kaneko F. H., Arf, O., Gitti, D. D. C., Arf M. V., Ferreira, J. P., Buzetti, S. (2010): Furrow opening mechanisms, inoculation of seeds and nitrogen fertilization in no tillage common bean crop. - Bragantia 69(1):125-33.

[29] Karasu, A., Oz, M. (2010): A study on coefficient analysis and association between agronomical characters in dry bean (Phaseolus vulgaris L.). - Bulgarian Journal of Agricultural Science 16(2): 203-211.

[30] Kaur, M., Singh, N. (2006): Relationships between selected properties of seeds, flours and starches from different chickpea cultivars. - International Journal of Food Properties 9: 597-608.

[31] Kigel, J. (1999): Culinary and nutritional quality of Phaseolus vulgaris L. seeds as affected by environmental factors. - Biotechnol Agron Soc Environ 3: 205-209.

[32] Kose, M. A., Ekbic, E., Arici, Y. K. (2019): Determination of protein, vitamins, amino acids and mineral element content of Yenice and Pinarlı bean (Phaseolus vulgaris L.) genotypes. - Turkish Journal of Food and Agriculture Sciences 1(1): 6-11.

[33] Kutoš, T., Golob, T., Kač, M., Plestenjak, A. (2003): Dietary fibre content of dry and processed beans. - Food Chemistry 80(2): 231-235.

[34] Maskey, S., Bhattarai, S., Peoples, M., Herridge, D. (2001): On-farm measurements of nitrogen fixation by winter and summer legumes in the hill and Terai regions of Nepal. Field Crop Research 70(3): 209-221. 
[35] Nascente, A. S., Carvalho, M. D. C. S., Melo, L. C., Rosa, P. H. (2017): Nitrogen management effects on soil mineral nitrogen, plant nutrition and yield of super early cycle common bean genotypes. - Acta Scientiarum. Agronomy 39(3): 369-378.

[36] Nelson, D., Sommers, L. (1982): Total Carbon, Organic Carbon and Organic Matter. - In: Page, A. L. et al. (eds.) Methods of Soil Analysis. Part 2 Chemical and Microbiological Properties. ASA, Madison, WI, pp. 539-579.

[37] Olsen, S. R. (1954): Estimation of Available Phosphorus in Soils by Extraction with Sodium Bicarbonate. - United States Department of Agriculture; Washington.

[38] Onder, M., Kahraman, A., Ceyhan, E. (2013): Correlation and path analysis for yield and yield components in common bean genotypes (Phaseolus vulgaris L.). - Ratarstvo i Povrtarstvo 50(2): 14-19.

[39] Oz, M. (2008): Nitrogen rate and plant population effects on yield and yield components in soybean. - African Journal of Biotechnology 7(24).

[40] Oz, M. (2002): Effect of different plant populations and nitrogen doses on yield and yield components of soybean in Bursa Mustafa Kemalpaşa ecological conditions. - Journal of Uludag University, Faculty of Agriculture 16: 165-177 (in Turkish with English abstract).

[41] Ozbekmez, Y. (2015): Determination of yield, yield components, seed and technological characteristics of some common bean (Phaseolus vulgaris L.) varieties and genotypes in Ordu ecological conditions. - Master Thesis, Ordu University, Institute of Science, Ordu, Turkey (in Turkish).

[42] Peksen, E (2005): Comparison of some common bean (Phaseolus vulgaris L.) genotypes for seed yield and yield related characteristics under Samsun conditions. - Ondokuzmayis University Journal of Agricultural Faculty 20(3): 88-95.

[43] Perina, E. F., Carvalho, C. R. L., Chiorato, A. F., Lopes, R. L. T., Gonçalves, J. G. R., Carbonell, S. A. M. (2014): Technological quality of common bean grains obtained in different growing seasons. - Bragantia 73(1): 14-22.

[44] Saha, S., Singh, G., Mahajan, V., Gupta, H. S. (2009): Variability of nutritional and cooking quality in bean (Phaseolus vulgaris L) as a function of genotype. - Plant Foods for Human Nutrition 64(2): 174-180.

[45] Sehirali, S. (1988): Edible Grain Legumes. - Ankara Univ. Faculty of Agric. Publication No: 1089, Ankara (in Turkish).

[46] Sepetoglu, H. (1994): Edible Grain Legumes. - Ege Univ. Faculty of Agric. Publication No: 24. Lecture Notes: 431, Izmir (In Turkish).

[47] Shimelis, E. A., Rakshit, S. K. (2005): Proximate composition and physico-chemical properties of improved common bean (Phaseolus vulgaris L.) varieties grown in Ethiopia. - LWT-Food Science and Technology 38(4), 331-338.

[48] Silim, S. N., Saxena, M. C. (1993): Yield and water use efficiency of faba bean sown at two row spacings and seed densities. - Experimental Agriculture 29: 173-181.

[49] Silva, G. C., Araujo, M. E. V., Almeida, V. F., Araújo, R. S., Lourenço, A. C. E., Lisboa, C. F., Teixeira, I. R., Silva, M. B., Sousa, W. S., Silva, A. G. (2020): Nitrogen fertilization management in common bean and castor bean intercropping systems. Australian Journal of Crop Science 14(5): 842-851.

[50] Smil, V. (2002): Biofixation and Nitrogen in the Biosphere and in Global Food Production. - In: Finan, T., O’Brian, M., Layzell, D., Vessey, K., Newton, W. (eds.) Nitrogen Fixation: Global Perspectives. CAB International, UK, pp. 7-9.

[51] Soratto, R. P., Catuchi, T. A., Souza, E. D. F. C. D., Garcia, J. L. N. (2017): Plant density and nitrogen fertilization on common bean nutrition and yield. - Revista Caatinga 30(3): 670-678.

[52] Thomas, G. W. (1982): Exchangeable Cations. - In: Page, A. L. et al. (eds.) Methods of Soil Analysis. Part 2 Chemical and Microbiological Properties. ASA, Madison, WI, pp. 159-165. 
[53] Valerio, C. R., Bastos de Andrade, M. J., Ferreira, D. F., Rezende, P. M. (2003): Common bean response to nitrogen doses at planting and topdressing. - Ciencia $\mathrm{E}$ Agrotecnologia, 27:1560-1568.

[54] Zahran, H. H. (1999): Rhizobium-legume symbiosis and nitrogen fixation under severe conditions and in an arid climate. - Microbiology and Molecular Biology Reviews 63(4): 968-989. 